\title{
The ecumenical vision of Pope Francis: journeying together as fellow pilgrims - 'the mystery of unity has already begun'
}

\section{Annemarie C. Mayer}

To cite this article: Annemarie C. Mayer (2017): The ecumenical vision of Pope Francis: journeying together as fellow pilgrims - 'the mystery of unity has already begun', International Journal for the Study of the Christian Church, DOI: $10.1080 / 1474225 X .2017 .1403840$

To link to this article: https://doi.org/10.1080/1474225X.2017.1403840

Published online: 27 Dec 2017.

Submit your article to this journal $₫$

View related articles $\longleftarrow$

View Crossmark data 5 


\title{
The ecumenical vision of Pope Francis: journeying together as fellow pilgrims - 'the mystery of unity has already begun'
}

\author{
Annemarie C. Mayer \\ KU Leuven, Leuven, Belgium
}

\begin{abstract}
After reviewing some of the unique ecumenical steps taken by Pope Francis, this article examines briefly the three ecumenical paragraphs in Evangelii Gaudium. It presents them in the wider context of this post-synodal exhortation, of the ecumenical gestures and testimonies of Pope Francis, the ecumenical orientation of the Catholic Church and the ecumenical movement as such. It concludes with an outlook on a newly emerging ecumenical paradigm.
\end{abstract}

\section{KEYWORDS}

Pope Francis; Evangelii Gaudium; Commemoration of the Reformation; polyhedron; synodality; ecumenism of hate; ecumenism of blood

\section{The Pope of the many 'firsts'}

With the election of Jorge Mario Cardinal Bergoglio SJ on 13 March 2013, the Catholic Church had its first non-European Pope in over 1200 years ${ }^{1}$ and its first Pope from Latin America ever. When Pope Francis appeared on the loggia, he commented: 'My brother Cardinals have gone to the ends of the earth to give Rome a bishop.' ${ }^{2}$ For the first time in 167 years, another Pope was elected who is a member of a religious order. ${ }^{3}$ Moreover, he is the first Jesuit Pope ever, and he is the first Pope to choose the name Francis. Referring back to St Francis of Assisi, this name stands for the major preferences of the Argentinean Pope, his preferential option for the poor and his emphasis on the respect of and care for creation. The uniqueness of these many 'firsts' is already making authors ask whether, in more recent papal history, Pope Francis should be likened to a brilliant-cut diamond solitaire. ${ }^{4}$

The question arises as to whether the uniqueness of Pope Francis also extends to the realm of ecumenical relations. In ecumenical respects there certainly are also a few 'firsts' that can be listed: He is the first Pope ever to visit the Waldensians ${ }^{5}$ and to invite the Salvation Army to the Vatican. Within the last thousand years, Pope Francis is the only Bishop of Rome at whose inauguration an Ecumenical Patriarch was present. He has subsequently established good co-operation with Patriarch Bartholomew. In May 2014, Pope and Patriarch visited

CONTACT Annemarie C. Mayer $\otimes$ annemarie.mayer@kuleuven.be

'Pope Gregory III (731-41) came from Syria.

${ }^{2}$ Ivereigh, The Great Reformer, 365. Since then this self-description of Francis has often been quoted to indicate that now a 'southern breeze' blows in the Catholic Church. Even book titles refer to it, for example, Craughwell, Pope Francis: The Pope from the End of the Earth.

${ }^{3}$ Pope Gregory XVI, who died in 1846, was a member of the order of the Camaldolese, who form part of the Benedictine monastic family.

${ }^{4} \mathrm{Cf}$. Ernesti, 'Papst Franziskus - ein Solitär der jüngeren Papstgeschichte?', 47-58.

${ }^{5}$ On the ecumenical impact of the Pope's visit to Turin in 2015 cf. Schmidt, 'Der Papst hat dafür den Ton angegeben', 107-10. 
the Holy Land together and commemorated the fiftieth anniversary of the historic meeting between Patriarch Athenagoras and Pope Paul VI, in Jerusalem on 5 January 1964. Pope Francis visited the Patriarch in November 2014 at the Phanar, ${ }^{6}$ and from 1 September 2015 introduced into the Catholic Church the World Day of Prayer for the Care of Creation, which the churches of the Ecumenical Patriarchate have commemorated since 1989 and which coincides with the beginning of the ecclesiastical year in the Orthodox Church.

For the first time since the founding of the Moscow Patriarchate in 1589/90 or, more precisely, for the first time since Pope Eugene IV met with Metropolitan Isidore of Kiev and Moscow at the Council of Ferrara in 1438/9, the Pope met with Patriarch Kirill of Moscow and All Russia on 12 February 2016, at Havana Airport, Cuba. One of the more tangible outcomes of this meeting was that the relics of St Nicholas travelled from Bari to Moscow and St Petersburg for veneration by the Russian faithful - saints, so to speak, as ambassadors and intercessors for unity. ${ }^{7}$

An absolutely unprecedented 'first time' was that Pope Francis not only accepted the personal invitation to the common commemoration of the $500^{\text {th }}$ anniversary of the Lutheran Reformation, ${ }^{8}$ which Christian Krause, the former president of the Lutheran World Federation handed to him in November 2014, but he even consented to co-host the Joint Commemoration ceremony on 31 October 2016, at the Lutheran Cathedral in Lund, actively participating in the common liturgy of thanksgiving, repentance and commitment to witness. ${ }^{9}$ Bishop Munib A. Younan, then President of the Lutheran World Federation, General Secretary Revd. Dr Martin Junge and the Pope liturgically expressed joint appreciation for the positive gifts of the respective communions, joint repentance for the division, violence and persecution that followed the Reformation and joint commitment to a common witness in the world. Together with the President of the Lutheran World Federation the Pope signed a Joint Statement ${ }^{10}$ during the liturgy in which, after 50 years of bilateral LutheranRoman Catholic dialogue, they declared their renewed commitment to give a more fervent testimony of faith in the Triune God, especially in the realm of diakonia, common service to fellow human beings. This commitment was corroborated by the signing of a Letter of Intent ${ }^{11}$ between Caritas Internationalis and the World Service Department of the Lutheran World Federation. With Lund as venue, this joint commitment gains special significance as a manifestation of the so-called 'Lund Principle'. As early as 1952, during its Third World Conference, the Faith and Order Commission of the World Council of Churches (in those days still without Roman Catholic members) encouraged the churches to ask themselves

\footnotetext{
${ }^{6} \mathrm{Cf}$. https://www.patriarchate.org/papalvisit (accessed August 23, 2017).

${ }^{7}$ Cf. e.g. the Vatican Radio reports on 21 May 2017, 'Major Relics of St Nicholas visit Russia' (http://en.radiovaticana.va/ news/2017/05/21/major_relics_of_st_nicholas_visit_russia/1313807), on 28 July 2017 'Relics of St Nicholas Return to Bari after Russian Tour' (http://en.radiovaticana.va/news/2017/07/28/relics_of_st_nicholas_return_to_bari_after_russian_tour/1327610) and Wooden, 'Communion of Saints can Intercede for Christian Unity, Cardinal Says', 28 July 2017, http://www.catholicnews.com/services/englishnews/2017/communion-of-saints-can-intercede-for-christian-unity-cardinal-says.cfm (all accessed August 23, 2017).

${ }^{8} \mathrm{Cf}$. the contributions by Theodor Dieter ('The Ecumenical Commemoration') and Kurt Cardinal Koch ('Why a Common Commemoration'), on the $500^{\text {th }}$ anniversary of the Lutheran Reformation, both in vol. 17 no. 1 (2017) of this journal.

${ }^{9} \mathrm{Cf}$. Lutheran World Federation and Pontifical Council for Promoting Christian Unity, From Conflict to Communion: LutheranCatholic Common Commemoration of the Reformation in 2017, also available on-line at https://www.lutheranworld. org/content/joint-common-prayer-lutheran-catholic-common-commemoration-reformation-2017 and https://www. lutheranworld.org/sites/default/files/lund_2016_program.pdf (both accessed August 23, 2017).

${ }^{10}$ Vatican Radio documents the Joint Statement at http://en.radiovaticana.va/news/2016/10/31/pope_and_president_of_ Iwf_sign_joint_statement/1269150 (accessed 23 August, 2017).

${ }^{11}$ For the Letter of Intent cf. https://www.lutheranworld.org/sites/default/files/declaration_of_intent_caritas_internationalis_and_Iwf_en.pdf (accessed August 31, 2017).
} 
'whether they should not act together in all matters except those in which deep differences of conviction compel them to act separately. ${ }^{12}$ The celebration in Lund opened a year of joint commemoration of the Reformation that has overcome any 'ecumenism of profiles' ${ }^{13}$ in the polemical sense of the word and stands instead for an ecumenism of strengths and assets. ${ }^{14}$

This is in strong contrast with any 'ecumenism of hate', as Antonio Spadaro SJ and Marcelo Figueroa state, taking recent developments in the United States into account. In their internationally widely acclaimed article in La Civiltà Cattolica (15 July 2017) the editor-in-chief of this Jesuit journal and the Argentinean Presbyterian pastor and editor-in-chief of the Argentinean edition of L'Osservatore Romano castigate some Catholics in the United States for forging ties with fundamentalist evangelicals for political purposes that result in a strange form of 'surprising ecumenism': 'Both Evangelical and Catholic Integralists condemn traditional ecumenism and yet promote an ecumenism of conflict that unites them in the nostalgic dream of a theocratic type of state. ${ }^{15}$ Integralist fundamentalism thus leads to the presence of opposing forms of ecumenism. As the most dramatic consequence of these two forms, the two authors refer to 'their contrasting perceptions of the faith and visions of the world where religions have irreconcilable roles. ${ }^{16}$ In fact, this 'strange ecumenism' can hardly be called ecumenism at all. The two authors point out: 'Clearly there is an enormous difference between these concepts and the ecumenism employed by Pope Francis with various Christian bodies and other religious confessions. His is an ecumenism that moves under the urge of inclusion, peace, encounter and bridges. ${ }^{17}$ They conclude: 'Here we can understand why the pontiff is so committed to working against "walls" and any kind of "war of religion."' 18 This means for the first time not only to call the church political, but also the political repercussions of the Pope's ecumenical vision. It is therefore now necessary to have a closer look at the underlying theological foundations of Pope Francis's ecumenical vision.

\section{Pope Francis's ecumenical programme in Evangelii Gaudium}

Evangelii Gaudium (EG) is the first programmatic text of the pontificate of Pope Francis. At first sight it seems to address ecumenical dialogue in a rather unspectacular way in only three paragraphs (EG 244-246). Moreover, this short passage does not seem to contain anything new. On the contrary, it comes in the form of a quite traditional style. As is common ecumenical practice, the Pope draws on Jesus' high priestly prayer in John 17:21 as the basis of ecumenical commitment. He then points out that the Christian proclamation

\footnotetext{
${ }^{12}$ Faith and Order Commission, The Third World Conference on Faith and Order, Lund, Sweden, 1952, no. 12, 190.

${ }^{13} \mathrm{Cf}$. the seminal Lutheran and Roman Catholic clarifications: Huber, 'Was bedeutet Ökumene der Profile?', 399-410; Lehmann, 'Was bedeutet “Ökumene der Profile"?', 411-21 as well as Oberdorfer, 'Konsensökumene? Differenzökumene? Ökumene der Profile?', 39-51.

${ }^{14} \mathrm{Cf}$. e.g. Lutheran World Federation and Pontifical Council for Promoting Christian Unity, From Conflict to Communion: Lutheran-Catholic Common Commemoration of the Reformation in 2017, 22: 'Ecumenical dialogue means being converted from patterns of thought that arise from and emphasize the differences between the confessions. Instead, in dialogue the partners look first for what they have in common and only then weigh the significance of their differences. These differences, however, are not overlooked or treated casually, for ecumenical dialogue is the common search for the truth of the Christian faith!'

${ }^{15}$ Spadaro and Figueroa, 'Evangelical Fundamentalism and Catholic Integralism in the USA: A Surprising Ecumenism', 15 July 2017: https://laciviltacattolica.com/uncategorized/evangelical-fundamentalism-and-catholic-integralism-in-the-usa-a-surprising-ecumenism/ (accessed 23 August, 2017).

${ }^{16}$ lbid.

${ }^{17}$ Ibid.

${ }^{18} \mathrm{Ibid}$. Schmidt, 'Der Papst hat dafür in Turin den Ton angegeben', 100-5 argues that the genuinely Jesuit imprint on the Pope's thinking and spirituality is responsible for this.
} 
would possess more credibility if Christianity were not divided - this is no new idea but was actually the motivation for the first World Mission Conference in Edinburgh in 1910. ${ }^{19}$ And finally, he quotes from Unitatis Redintegratio 4 that there also ought to be attained 'the fullness of catholicity proper to her [i.e. the Church] in those of her sons who, though joined to her by baptism, are yet separated from full communion with her.'20

Yet this familiar picture then suddenly changes dramatically: 'We must never forget that we are pilgrims journeying alongside one another. This means that we must have sincere trust in our fellow pilgrims, putting aside all suspicion or mistrust, and turn our gaze to what we are all seeking: the radiant peace of God's face. Trusting others is an art, and peace is an art', we read in Evangelii Gaudium (244). Depending on the circumstances of the pilgrimage route, fellow pilgrims can be essential for survival. During such a pilgrimage trust not only in God, but also in one's companions, is indispensable. Taking the metaphor of the companionship of pilgrims seriously, does this mean that, potentially, all of us can be on the right path together or likewise, all of us can commonly go astray? Is there a guarantee that we are proceeding together on the right way? For Francis, unity is by no means a static state, but an event, a process, because it comes about by journeying together on a common path. ${ }^{21}$ Thus, unity is not just an aim or a point of reference; it is, rather, an indicator that we are on the right way. The aim of this pilgrimage is, according to the Pope, that 'we are all seeking the radiant peace of God's face' (EG 244). Thus, intra-Christian ecumenism is placed in a worldwide, historical and salvation-historical context and interpreted as 'a contribution to the unity of the human family' (EG 245). That is to say, the subject is not dealt with under purely ecclesiological aspects, which nowadays seem less and less relevant, but placed under heading IV. Social Dialogue as a Contribution to Peace (EG 238-258). In today's global situation a topic can hardly be more up-to-date!

The subheading Ecumenical Dialogue follows reflections on Dialogue between Faith, Reason and Science (EG 242-243) and precedes Relations with Judaism (EG 247-249) and reflections on Interreligious Dialogue (EG 250-254), which are in turn still followed by Social Dialogue in a Context of Religious Freedom (EG 255-258). This embedding of ecumenism in the various dialogues of the Church is programmatic for Pope Francis. Time and again he points out that ecumenism is not to be a 'stew in one's own juice'. Therefore it is not a standstill but a movement, and this movement takes place in dialogue, mutual listening and learning from each other. ${ }^{22}$ Following in the footsteps of John XXIII, Pope Francis is convinced that what unites us is more than what divides us. Enthusiastically he exclaims: 'How many important things unite us! If we really believe in the abundantly free working

\footnotetext{
${ }^{19}$ Towards such initiatives Rome initially took a reserved or even opposing stance. In 1919 the Holy Office forbade Catholics from becoming members of ecumenical associations. In 1928 the Encyclical Mortalium Animos confirmed this interdiction. ${ }^{20}$ Second Vatican Council, 'Decree on Ecumenism Unitatis Redintegratio' (1965) 4, $413 f$.

${ }^{21}$ This the Pope re-emphasises time and again, e.g. in his impressive exhortation to progress on the way towards full visible unity in the context of an intercession for forgiveness during the closing worship of the Week of Prayer for Christian Unity on 26 January 2016 in St Paul's Outside the Walls, cf. http://www.osservatoreromano.va/en/news/unity-journey (accessed August 23, 2017). In attributing this high value to the'path', Pope Francis is absolutely consistent with the spiritual journey he already advocated before he became Pope. Cf. Bergoglio and Skorka, On Heaven and Earth, 2: 'What a great word: path! In my personal experience with God I cannot do without the path. I would say that one encounters God walking, moving, seeking Him and allowing oneself to be sought by Him. They are two paths that meet. [...] Because of this I say that my experience with God takes place along the path, both in the search and in allowing myself to be sought, even if it may be by diverse paths - of pain, of joy, of light or of darkness.'.

${ }^{22} \mathrm{Cf}$. O'Collins, 'Pope Francis and the Second Vatican Council', 214:' where Vatican Il urged dialogue with these "other Christians", he speaks frankly about what Catholics can learn from them: for instance, in the practice of "episcopal collegiality and their experience of synodality".."
} 
of the Holy Spirit, we can learn so much from one another! It is not just about being better informed about others, but rather about reaping what the Spirit has sown in them, which is also meant to be a gift for us' (EG 246). As fellow pilgrims, trusting in the guidance of the Holy Spirit, we all can learn from each other's otherness. The Pope is not concerned with the fact that the Catholic Church should apathetically 'tolerate' the otherness of others (in a misunderstood sense of 'tolerance'), but that she understands this otherness as an inspiration for her own self-understanding.

Formally speaking, Evangelii Gaudium is the post-synodical exhortation on the Bishops' Synod on the New Evangelisation. Therefore, the Pope wishes to contrast 'the counter-witness of division among Christians' (EG 246) with a common positive witness of Christian unity, which is likely to facilitate evangelisation, especially in Asia and Africa. It is noteworthy that Francis does not relate his reflections to a denominationally limited testimony, but that, in alignment with the principle of the hierarchy of truths, he wants 'to progress decidedly towards common expressions of proclamation, service and witness' (EG 246). Ecumenism is at the service of evangelisation, for, according to Evangelii Gaudium 246, '[t] he immense numbers of people who have not received the gospel of Jesus Christ cannot leave us indifferent. Consequently, commitment to a unity which helps them to accept Jesus Christ can no longer be a matter of mere diplomacy or forced compliance, but rather an indispensable path to evangelization' (EG 246). Unity is far from being an end in itself; it has to serve the 'receiving of Jesus Christ'.

After this brief overview of the three ecumenical paragraphs, I would now like to present my reading of their text in the wider context of Evangelii Gaudium, the ecumenical gestures and testimonies of Pope Francis, the ecumenical orientation of the Catholic Church and the ecumenical movement as such. I shall conclude with an outlook on a new emerging ecumenical paradigm.

The initial paragraphs of Evangelii Gaudium draw a picture of the present Church, which is characterised by cumbersomeness, lack of enthusiasm and perhaps even futility (at least in the perception of many people). Christians themselves are by no means innocent with regard to this perception of their church(es). 'There are Christians whose lives seem like Lent without Easter' (EG 6) - the Pope says unequivocally and self-critically.

Simultaneously, the image of the current stagnation of ecumenism, which is often summarised today in the metaphors of an 'ecumenical winter' or even an 'ecumenical ice age', could be juxtaposed. Impatiently one demands that the ecumenical movement should not come to a halt, but move on. However, the fact is easily overlooked that ecumenism also has to take seriously and integrate new realities. Many churches are in a state of tension: they are tempted to classify ecumenism as secondary, in view of far more pressing problems internally as well as on a worldwide level. On the other hand, they are confronted with an ecumenism of life style and emotions, which pretends to yield astonishing success in achieving unity without taking into account any 'theological quibbles'. Ecumenism today has to come to terms with an ambivalent phenomenon: on the one hand there is the growing indifference towards religious practice according to the motto 'Anything goes' ${ }^{23}$ on the other, there is a growing trend towards an excessive assertion of religious identities, following the

\footnotetext{
${ }^{23} \mathrm{Cf}$. e.g. Müller-Fahrenholz, 'Zwischen Fundamentalismus und Beliebigkeit', 68-76 as well as Anhelm, 'Fundamentalismus und Beliebigkeit - pathologische Begleiterscheinungen der Moderne?', 77-9 or Mayer, 'Was liegt heute prospektiv für Theologie und Kirche in ökumenischer Hinsicht an?', 238-54.
} 
so-called TINA principle, the acronym for: 'There is no alternative!'24 In each church family there are anti-ecumenical tendencies. There is not only a growth in agreement, ${ }^{25}$ but also in division and fragmentation.

However, given the present state of affairs, there are, above all, quite a lot of reasons for a grateful retrospect: the ecumenical movement was one of the most distinctive 'signs of the times' or features of the twentieth century. Much of what has been painstakingly achieved in the past hundred years is now a common practice of our churches and self-evident to us. And so it should be! Where church fellowship and church communions have been achieved, they so far have lasted permanently. Where there is still ecumenical need for clarification, a variety of dialogues and consensus documents have already emerged as the expression of a new fellowship of the churches. One might sometimes wish for a wider reception and practical implementation of them. Currently ecumenism seems to be in a kind of refocusing phase, in which, following the successes of the initial phase and a subsequent phase of consolidation, it has reached a point of transition in which the major task is to consider the next sensible steps. Yet all this can also give the impression of stalling and even of a complete standstill. The fact that much has already been achieved does not spare us from a critical glance at the present. Such a critical view of the present situation is risked by Pope Francis in Evangelii Gaudium 99f., when he points out that old conflicts and divisions, which have long since been deemed to be overcome, are still present. They can break open again any time. Therefore he 'ask[s] Christians in communities throughout the world to offer a radiant and attractive witness of fraternal communion. Let everyone admire how you care for one another, and how you encourage and accompany one another: "By this everyone will know that you are my disciples, if you have love for one another" (John 13:35).'

Human beings in general, but above all Christians, are never an island, but lead a relational existence. This anthropological insight Pope Francis already points out in his very first encyclical, Lumen Fidei, which was published three months after his election:

Persons always live in relationship. We come from others, we belong to others, and our lives are enlarged by our encounter with others. Even our own knowledge and self-awareness are relational; they are linked to others who have gone before us: in the first place, our parents, who gave us our life and our name. Language itself, the words by which we make sense of our lives and the world around us, comes to us from others, preserved in the living memory of others. Self-knowledge is only possible when we share in a greater memory. The same thing holds true for faith, which brings human understanding to its fullness. ${ }^{26}$

A Christian knows him- or herself in relation with fellow believers, with the cloud of witnesses through the ages. Yet the relation with God is the most important relation. The high appreciation of the relation with God is something which Pope Francis values in other church traditions, especially in the Lutheran tradition.

The spiritual experience of Martin Luther challenges us to remember that apart from God we can do nothing. 'How can I get a propitious God?' This is the question that haunted Luther. In effect, the question of a just relationship with God is the decisive question for our lives. As we know, Luther encountered that propitious God in the Good News of Jesus, incarnate, dead

\footnotetext{
${ }^{24}$ The French sociologist Pierre Bourdieu coined this slightly ironic acronym for a certain pattern employed by politicians to justify their decisions in public. Especially Margaret Thatcher's speeches contained that phrase to a high degree. Hence, her biographer chose this title, cf. Berlinski, There Is No Alternative: Why Margaret Thatcher Matters.

${ }^{25}$ Four volumes of ecumenical documents with the general title Growth in Agreement have already been published. For the most recent, see Best, Fuchs, Gibaut, Gros and Prassas, eds. Growth in Agreement, vol. IV, book 1 and book 2.

${ }^{26}$ Francis, 'Encyclical Letter on Faith Lumen Fidei (29 June, 2013)', no. 38.
} 
and risen. With the concept 'by grace alone', he reminds us that God always takes the initiative, prior to any human response, even as he seeks to awaken that response. The doctrine of justification thus expresses the essence of human existence before God. ${ }^{27}$

Moreover, in Evangelii Gaudium it becomes very clear that for Pope Francis the gospel is always the starting point. This almost seems like a papal 'sola Scriptura' principle in the best, non-apologetic sense. 'Take Christ out of Scripture, what will you find in it?'28 With this question from Martin Luther's De servo arbitrio [From the enslaved will], the Christocentric interpretation consistently presented in Evangelii Gaudium is perhaps characterised in the most befitting way. Based on the principle of a hierarchy of truths (UR 11), explained in Evangelii Gaudium 36 and 246, the Pope insists on a primacy of the proclamation of Jesus Christ. Evangelii Gaudium 110 explains this in accordance with John Paul II:

There can be no true evangelisation without the explicit proclamation of Jesus as Lord, '[... and however this proclamation will happen] the joyful, patient and progressive preaching of the saving death and resurrection of Jesus Christ must be your absolute priority.' These words hold true for all of us. ${ }^{29}$

Thus 'solo Christo' is the underlying motivation for 'sola Scriptura' and 'sola gratia'.

It is not only that Pope Francis focuses evangelisation on 'was Christum treibet' - 'what promotes Christ'; ${ }^{30}$ he also does not refer in the least to any christocentric-exclusive documents of the Curia that might be thematically relevant, such as Dominus Iesus. ${ }^{31}$ Against this whole background, it does not seem so astonishing or even absurd that this Pope personally took part in the commemoration of the Reformation which the Lutheran World Federation celebrated on 31 October 2016 in Lund, although this courageous step surprised many, disconcerted others and even scandalised some.

\section{'The mystery of unity has already begun'}

Yet another passage in Evangelii Gaudium is most remarkable in an ecumenical respect. Under III. The Common Good and Peace in Society, Francis formulates principles which he deems important, such as 'Time is greater than space' (EG 222), 'Unity prevails over conflict' (EG 226), 'Realities are more important than ideas' (EG 231) and 'The whole is greater than the part' (EG 234). ${ }^{32}$ In connection with this latter principle, in the context of his reflections on communion, universality and particularity, Pope Francis explains his polyhedral aim of unity and diversity:

\footnotetext{
${ }^{27}$ Francis, 'Sermon at the Common Ecumenical Prayer at the Lutheran Cathedral of Lund (31 October, 2016)'.

${ }^{28}$ Luther, De servo arbitrio; 1525, WA 18, 606, 29.

${ }^{29}$ In Evangelii Gaudium (110) Francis quotes extensively from John Paul II, 'Post-Synodal Apostolic Exhortation Ecclesia in Asia (6 November, 1999)', no. 19, 478. John Paul II states ibid., no. 2, 451: 'If the Church in Asia is to fulfil its providential destiny, evangelization as the joyful, patient and progressive preaching of the saving Death and Resurrection of Jesus Christ must be your absolute priority.'.

${ }^{30}$ Luther, 'Preface to Commentary on the Letter of James / Vorrede zum Jakobusbrief (1522/1546)'WA DB VII, 385, 25-32:'Vnd darinne stimmen alle rechtschaffene Buecher vber eins, das sie alle sampt Christum predigen vnd treiben. Auch ist das der rechte Pruefestein alle Buecher zu taddeln, wenn man sihet, ob sie Christum treiben oder nicht, Sintemal alle schrifft Christum zeiget, Rom. iij. Vnd S. Paulus nichts denn Christum wissen wil, j. Cor. ij. Was Christum nicht leret, das ist noch nicht Apostolisch, wens gleich S. Petrus oder Paulus leret. Widerumb, was Christum prediget, das were Apostolisch, wens gleich Judas, Hannas, Pilatus, vnd Herodes thet ...'

${ }^{31}$ Especially the paragraphs Dominus lesus 16-18 would have offered themselves as a reference to a text written by his immediate predecessor, cf. http://www.vatican.va/roman_curia/congregations/cfaith/documents/rc_con_cfaith_ doc_20000806_dominus-iesus_en.html (accessed August 23, 2017).

${ }^{32}$ On the background of these principles in the Latin American Theology of the People cf. Scannone, 'Pope Francis and the Theology of the People', 128-30.
} 
'Here our model is not the sphere, which is no greater than its parts, where every point is equidistant from the centre, and there are no differences between them. Instead, it is the polyhedron, which reflects the convergence of all its parts, each of which preserves its distinctiveness' (EG 236).... 'Pastoral and political activity alike seek to gather in this polyhedron the best of each' (EG 236). ${ }^{33}$

Since then, Pope Francis has often referred to and elaborated on this new metaphor for unity in diversity in the context of ecumenism. ${ }^{34}$ The concept of the relationship of the Catholic Church to other churches and ecclesial communities, as well as to other religions and even to non-believers, as indicated in Lumen Gentium (14-16), was welcomed as progress in post-conciliar ecclesiology and often visualised in concentric circles with the Catholic Church at the centre. ${ }^{35}$ Yet thinking in the figure of a polyhedron, instead of in concentric circles or the shape of a sphere, opens up considerably more leeway for unity in diversity, even if it is not so easy to calculate the centre of gravity of such a figure. This diversity must not only be related to the relationship between the Catholic Church and its ecumenical conversation partners; it can also be localised on the part of each of the interlocutors themselves. A polyhedron appears to be able to withstand certain centrifugal forces and is therefore suited to 'gather the best of every individual' (EG 236). Such centrifugal forces are at work in every church tradition. Perhaps the most straightforward example to show how a polyhedral relation can work is that of Pope Francis and the Patriarchs of Constantinople and Moscow. On 12 February 2016, Pope Francis welcomed Patriarch Kirill of Moscow saying, 'Finally! We are not rivals, but brothers ..... ${ }^{36}$ This meeting, the first in the history of the two churches, even if it had to take place on 'neutral' territory in Cuba, would have been unthinkable, when Bergoglio took on his office. And this was the case not least because the Ecumenical Patriarch Bartholomew himself was also present at Francis' installation likewise an event which had never taken place since 1054, if ever at all.

As early as 1977, at its Plenary Assembly in Dar es Salaam, the Lutheran World Federation had proposed the model of 'unity in reconciled diversity'. It intended to present a concept that would conceive of the unity sought by the Church not as a simple unification in the sense of a fusion of existing churches or as the absorption of one church into another. Unity should not be confused with uniformity. On the other hand, ignored conflicts and differences should not be labelled as unity. The fact that Pope Francis thinks along the lines of the model of 'unity in reconciled diversity' is already apparent from the book he published together with Rabbi Abraham Skorka On Heaven and Earth, where Bergoglio expressly refers to Oscar Cullmann's concept of 'unity through diversity' which manifests itself in walking

\footnotetext{
${ }^{33}$ Already before Francis became Pope he used the polyhedron as a metaphor; Bergoglio and Skorka, On Heaven and Earth, 157: 'The true globalization, that which we must defend, is like a polyhedron in which everyone is integrated but each player maintains his particularities, which, at the same time, enrich the others..'

${ }^{34}$ Francis, 'Personal visit of His Holiness Pope Francis to Caserta to meet with the evangelical pastor Giovanni Traettino', 28 July 2014: 'We are in the era of globalisation, and we reflect on what globalisation is and what unity in the church could be: Perhaps a sphere, where all points are equidistant from the centre? No! This is uniformity. And the Holy Spirit does not do uniformity! What figure can we find? We think of the polyhedron: the polyhedron is a unity, but with all its parts being different. Each one has its peculiarity, its charism. This is unity in diversity. And along this route we Christians do what we call ecumenism: we try to bring about that this diversity is more harmonised by the Holy Spirit and becomes unity; we try to walk towards the presence of God in order to be faultless/impeccable; we try to go and find the nourishment which we need to find our brother. This is our way, this is our Christian beauty!' (http://press.vatican.va/content/salastampa/de/ bollettino/pubblico/2014/07/28/0542/01200.html; accessed 23/08/2017; my translation).

${ }^{35} \mathrm{Cf}$. Second Vatican Council, 'Dogmatic Constitution on the Church Lumen Gentium', 333-5.

${ }^{36} \mathrm{Cf}$. 'Meeting of His Holiness Pope Francis with His Holiness Kirill, Patriarch of Moscow and All Russia' (12 February 2016).
} 
together 'without nullifying the diverse traditions or falling into syncretism. ${ }^{37}$ Cullmann was, at the time of Vatican II, a Reformed observer of the Council.

This conviction is particularly expressed in the personal dialogue conducted by Pope Francis with Pentecostals and evangelicals. He visited for instance the Catholic Fraternity of Charismatic Covenant Communities and Fellowships (31 October 2014); he went to Caserta to a meeting with the evangelical pastor Giovanni Traettino (28 July 2014); in January 2014 he met with the Anglican evangelical Bishop Anthony Palmer who was the ecumenical representative of the Evangelical Episcopal Churches (CEEC) but sadly died in a motorcycle accident in summer 2015. In February 2014, Pope Francis, during an act of worship led by the evangelical preacher Kenneth Copeland, in which Palmer also took part, addressed himself in a video message directly to Copeland and the charismatic movement: 'Let us embrace each other spiritually, and let God complete the work he has begun. And this is a mystery; the mystery of unity has already begun. ${ }^{38}$ These contacts are remarkable in view of the difficulties encountered by other institutions, for instance by the World Council of Churches, when it comes to establishing and maintaining an official and more or less reliable relationship with Pentecostal and evangelical charismatic organisations. ${ }^{39}$ Certainly, since 1972 the Roman Catholic Church, through the Pontifical Council for Promoting Christian Unity, has had an official dialogue with representatives of some of the Pentecostal Churches. This is unique in that it is conducted with individuals who are not officially delegated through an instituted church body. In part, this is even against the explicit protest of the churches to which they belong. The starting point for common dialogue is the shared charismatic renewal and the experience of the activity of the Spirit. Nevertheless, by and large, this dialogue as a whole has been treated somewhat negligently in the bilateral dialogues of the Roman Catholic Church until now. Through the efforts of the Pope, it has greatly increased its value and now corresponds more adequately to the quantitative relationship between Pentecostals and Catholics worldwide.

By referring to the 'mystery of unity', Pope Francis also positions himself in the tradition of his predecessors and calls to mind Gaudet Mater Ecclesia, Pope John XXIII's speech at the opening of the Second Vatican Council, on 11 October 1962:

The Catholic Church, therefore, considers it her duty to work actively so that there may be fulfilled the great mystery of that unity, which Jesus Christ invoked with fervent prayer from His heavenly Father on the eve of His sacrifice. ${ }^{40}$

For Francis, therefore, unity is not only peace and harmony, although he emphasises again and again that unity weighs more than conflict (EG 227-230), and the whole is superior

\footnotetext{
${ }^{37} \mathrm{Cf}$. Bergoglio and Skorka, On Heaven and Earth, 217f.:'He says we should not seek that everyone, from the outset, affirm the same thing, but instead he proposes that we walk together in a reconciled diversity; he resolves the religious conflict of the many Christian denominations by walking together, by doing things together, by praying together. He asks that we not throw rocks at each other, but rather that we continue walking together. It is the way of advancing the resolution of a conflict with the virtues of all, without nullifying the diverse traditions or falling into syncretism. Each one, from their identity, in reconciliation, seeking the unity of truth.'

${ }^{38} \mathrm{Cf}$. Francis, 'Video Message', https://www.youtube.com/watch?t=136\&v=NZ9Ssvs5cgY (accessed on August 23, 2017).

${ }^{39}$ The General Secretary of WCC Olav Fykse Tveit was only granted a few marginal words at the Cape Town Conference. Nevertheless WCC celebrated this as a big success. The difference in assessing this becomes obvious when one compares the websites of the two institutions https://www.lausanne.org/gatherings/congress/cape-town-2010-3 (without reference to WCC) https://www.oikoumene.org/en/resources/documents/general-secretary/speeches/greetings-to-the-3rd-lausannecongress-for-world-evangelization and https://www.oikoumene.org/en/press-centre/news/wcc-delegates-join-in-celebrating-reconciliation-at-cape-town-event (accessed August 23, 2017).

${ }^{40} \mathrm{John}$ XXIII, 'Gaudet Mater Ecclesia (11 October, 1962)', 793. English translation at http://vatican2voice.org/91docs/opening_speech.htm (accessed 23/08/2017).
} 
to the part and thus more than the sum of its parts. Unity is also something that grows in dialogue and therefore requires a Church of dialogue and a Church open to dialogue. ${ }^{41}$ The Catholic Church saw a prominent example of the attempt to start an open dialogue internally at the Bishops' Synod in October 2015. Francis had attempted to put into practice the primacy of time over place (EG 222-225) by initiating processes which he hoped would be irreversible in the course of time. The letter of the 13 cardinals, written during the Synod, indicates that the importance of such processes is not underestimated by those who oppose them either. ${ }^{42}$

Another example in Evangelii Gaudium itself is the open dialogue which Pope Francis wishes to foster on the way the papacy is exercised. He remarks self-critically:

Since I am called to put into practice what I ask of others, I too must think about a conversion of the papacy. It is my duty, as the Bishop of Rome, to be open to suggestions which can help make the exercise of my ministry more faithful to the meaning which Jesus Christ wished to give it and to the present needs of evangelization. Pope John Paul II asked for help in finding 'a way of exercising the primacy which, while in no way renouncing what is essential to its mission, is nonetheless open to a new situation'. We have made little progress in this regard. The papacy and the central structures of the universal Church also need to hear the call to pastoral conversion. (EG 32) ${ }^{43}$

Such criticism of a predecessor is unique. On the topic of the 'conversion of the papacy' in Evangelii Gaudium (32), much ink has already flowed and a separate contribution would have to be written. ${ }^{44}$ In Evangelii Gaudium (16), Pope Francis himself already finds clear words and formulates guidelines for his conception of an ecumenically justifiable primacy: 'It is not advisable for the Pope to take the place of local Bishops in the discernment of every issue which arises in their territory. In this sense, I am conscious of the need to promote a sound "decentralization" (EG 16). This very same conviction Francis also expressed on the loggia immediately after his election, when he presented himself to the waiting crowd as the 'Bishop of Rome' - a title that is ecumenically acceptable to many churches and ecclesial communities.

The decisive point for Francis is the relationship between collegiality and synodality on the one hand, and primacy on the other. This question had already caused quite a stir at the time of Vatican II, for example during the so-called 'Black Week'. Not only the postponing of the vote on Dignitatis Humanae, the Decree on Religious Freedom, and the presentation of a nota praevia explicativa to Lumen Gentium, the Dogmatic Constitution on the Church, but above all the direct intervention of Pope Paul VI, in the formulation of Unitatis Redintegratio and his insistence on the title 'Mother of the Church' for the Blessed Virgin, called into question the Council's synodality and collegiality. Such interventions by a seemingly absolutist primacy made any of the Council's statements on synodality and collegiality seem more than questionable. ${ }^{45}$ Since then the same question has remained a hot topic both with regard to intra-Catholic affairs and ecumenically.

\footnotetext{
${ }^{41} \mathrm{Cf}$. Bevans, 'The Apostolic Exhortation Evangelii Gaudium on the Proclamation of the Gospel in Today's World: implications and prospects', 297-308 states that Evangelii Gaudium wants to put into practice the ideal of a Church in dialogue.

${ }^{42}$ See the letter of the 13 cardinals to Pope Francis, with comment by Sandro Magister, at http://chiesa.espresso.repubblica.it/ articolo/1351154bdc4.html?eng=y\&refresh_ce (accessed August 23, 2017) and the official Vatican reaction at http://www. news.va/en/news/fr-lombardi-on-the-letter-to-the-pope-from-thirtee (accessed August 23, 2017).

${ }^{43}$ Cf. John Paul II, 'Encyclical Letter Ut Unum Sint (25 May, 1995)', 95, 977-8.

${ }^{44}$ E.g. Wąsek, 'Neuausrichtung des Papsttums - Legitimität, Konfliktpunkte und Wandel', 366-78. Cf. also O'Connell, 'Francis Calls for Decentralization and "Conversion" of the Papacy', 9.

${ }^{45} \mathrm{Cf}$. Tagle, 'The "Black Week" of Vatican II (November 14-21 1964)', 388-452, who also discusses some good reasons for the decisions of Pope Paul VI.
} 


\section{Broadening the denominational perspective}

Sometimes it is helpful to examine how others, for whom synodality is more self-evident, deal with similar problems in a synodical way. I refer, therefore, to the gathering of the Primates of the Anglican Communion, convened by the Archbishop of Canterbury in January 2016. The purpose of this gathering was to clarify how in future the Anglican Communion would organise the relation of its member churches to each other and to the see of Canterbury. Would there still be full communion between all individual member churches? What should the future role of the Archbishop of Canterbury in this revised Communion be, for the differences in ethical issues, caused by a change in the marriage canons of the Episcopal Churches in the USA and Canada in summer 2015, seemed irreconcilable.

It is already remarkable that the Archbishop pointed out in his invitation to the Primates: 'We have no Anglican Pope. Our authority as a church is dispersed, and is ultimately found in Scripture, properly interpreted.46 This was indeed a reference to the papacy, which caused some ecumenical irritation. Yet the Archbishop of Canterbury merely intended to emphasise that problems in the Anglican Communion are not to be solved by the decision of an individual but only synodically. And as we have seen, Pope Francis, in Evangelii Gaudium, insists that papal primacy and orientation towards Holy Scripture do not have to form mutually exclusive alternatives.

In his presidential address to the General Synod of the Church of England on 15 February 2016, the Archbishop of Canterbury reviewed the latest events:

One of the moments in which we voted [...] was on the question, when all seemed lost, as to whether we would walk together or separately. And it did seem lost. The vote to walk together, after a warning - repeated twice - that to undertake to do so meant to take a personal responsibility for it happening properly, was unanimous. It was done by open voting of raised hands, and was total. However, the divisions were profound, and remain so. We should not have any illusions of the fragility of the process, or of the outcome. ${ }^{47}$

He continued with an explanation that the provinces of the Anglican Communion are autonomous, but still interdependent. This means that none of the church provinces can be canonically bound by a decision of the Communion, not even of a formal Primates' Meeting. Nevertheless, consequences are the natural result, if a church province decides to act outside the traditional doctrine in such a way that it has a lasting effect on the whole Communion. ${ }^{48}$ As a consequence of their gender-neutral reformulation of the marriage canons, the Episcopal Churches in the United States and Canada are now called upon not to represent the Anglican Communion ecumenically or in other respects because they are currently not in harmony with the other provinces of the Anglican Communion. Archbishop Welby finished his retrospect with the significant sentence: 'There is no church order that ensures perfection, nor one in which human sin does not add to the problems of the whole. ${ }^{39}$

\footnotetext{
${ }^{46} \mathrm{Cf}$. the article Archbishop of Canterbury Calls for Primates' Gathering dating from 16 September 2015; http://www.archbishopofcanterbury.org/articles.php/5613/archbishop-of-canterbury-calls-for-primates-gathering- (accessed 23 August, 2017).

${ }^{47}$ Welby, 'Presidential Address to the General Synod of the Church of England (15 February, 2016)'.

${ }^{48} \mathrm{Cf}$. ibid: 'Where a Province decides to take action that has a profound effect on other Provinces, either because it is outside of the received doctrine of the Communion or through its day-to-day impact (in this case both), then there will be consequences. That seems obvious; actions have results.' ${ }^{49}$ lbid.
} 
On the occasion of the conclusion of the XIV th Ordinary General Assembly of the Bishops' Synod on 24 October 2015, Pope Francis points to a quite similar experience of entanglement in sin:

In the course of this Synod, the different opinions which were freely expressed - and at times, unfortunately, not in entirely well-meaning ways - certainly led to a rich and lively dialogue; they offered a vivid image of a church which does not simply 'rubberstamp', but draws from the sources of her faith living waters to refresh parched hearts. ${ }^{50}$

This almost seems like a commentary on Justin Welby's remarks on the differences between the various church provinces of the Anglican Communion which Francis wants the Anglican Communion to take good note of, when the Pope continues to elaborate on the experiences of the synod members with continental differences:

And - apart from dogmatic questions clearly defined by the Church's Magisterium - we have also seen that what seems normal for a bishop on one continent, is considered strange and almost scandalous - almost! - for a bishop from another; what is considered a violation of a right in one society is an evident and inviolable rule in another; what for some is freedom of conscience is for others simply confusion. Cultures are in fact quite diverse, and every general principle $[\ldots]$ needs to be inculturated, if it is to be respected and applied..$^{51}$

Pope Francis values synodality very highly, but not for mainly ecumenical reasons: at the fiftieth anniversary of the institution of the synod of bishops he argues with the sensus fidelium, the sense of the faithful, "These are the famous words infallible "in credendo"' 52 and he refers to Evangelii Gaudium (119). On the one hand, the sensus fidelium, with its 'infallible in credendo', is not only a healthy counterbalance to, but also a theological basis for, the Pope's infallibility. On the other hand, synodality, with its integration of the entire People of God, pursues the goal of opening up. According to Francis, the synod was also about

trying to open up broader horizons, rising above conspiracy theories and blinkered viewpoints, so as to defend and spread the freedom of the children of God, and to transmit the beauty of Christian Newness, at times encrusted in a language which is archaic or simply incomprehensible. ${ }^{53}$

This is a clear description of what Pope Francis sees as the tasks of a synod. In this task description, a number of ecumenical convergence points could again be identified, but this would lead us too far.

\section{An emerging ecumenical paradigm}

Heterogeneity necessitates a dialogical involvement. This not only holds true for ecumenical dialogue but for all forms of dialogue.

Dialogue is born from a respectful attitude toward the other person, from a conviction that the other person has something good to say. It supposes that we can make room in our heart for their point of view, their opinion and their proposals. Dialogue entails a warm reception and not a preemptive condemnation. To dialogue, one must know how to lower the defences, to open the doors of one's home and to offer warmth. ${ }^{54}$

\footnotetext{
${ }^{50}$ Francis, 'Address of his Holiness Pope Francis in Conclusion of the Synod of Bishops (24 October, 2015)'.

${ }^{51}$ Ibid.

${ }^{52} \mathrm{Francis}$, 'Address of his Holiness Pope Francis at the Ceremony Commemorating the 50th Anniversary of the Institution of the Synod of Bishops (17 October, 2015)'.

${ }^{53}$ Francis, 'Address of his Holiness Pope Francis in Conclusion of the Synod of Bishops (24 October, 2015)'.

${ }^{54}$ Bergoglio, 'The Façade as a Mirror' in Bergoglio and Skorka, On Heaven and Earth, XIII-XVI, XIV.
} 
After the first meeting of the new Pope with the representatives of the churches and ecclesial communities, as well as of the different religions in the Sala Clementina on 20 March $2013,{ }^{55}$ ecumenical circles had voiced their criticism that Francis focused on inter-religious dialogue at the expense of ecumenical exchange. By the publication of Evangelii Gaudium, at the latest, it should have become clear that the Pope's interest is in dialogue as such as a means to promote peace and welfare of all people. Already in his speech at the time, in March 2013, there were clear indications of this attitude, e.g. when he states:

The Catholic Church is conscious of the importance of promoting friendship and respect between men and women of different religious traditions [...] There is much that we can do to benefit the poor, the needy and those who suffer, and to favour justice, promote reconciliation and build peace. [...] We know how much violence has resulted in recent times from the attempt to eliminate God and the divine from the horizon of humanity, and we are aware of the importance of witnessing in our societies to that primordial openness to transcendence which lies deep within the human heart. ${ }^{56}$

It is precisely in connection with this last point, the problem of religiously motivated violence, be it used to defend religion or to defend oneself against religion, that Pope Francis is currently developing a new ecumenical paradigm that goes beyond Evangelii Gaudium, the paradigm of an ecumenism of the blood of the martyrs of all churches. ${ }^{57}$ After the Reformation the concept of 'martyr' was denominationally narrowed down: those whom one side venerated as martyrs were regarded as pernicious heretics and often as villains by the other. On the basis of our common baptism, the Second Vatican Council had tried to broaden this tunnel vision again by pointing out that non-Catholic Christians are also 'bearing witness to Christ sometimes even to the shedding of their blood' ${ }^{58}$ When commemorating the martyrs of the twentieth century, Pope John Paul II pointed in particular to the ecumenical implications of their witness: 'Perhaps the most convincing form of ecumenism is the ecumenism of the saints and of the martyrs. The communio sanctorum speaks louder than the things which divide us. ${ }^{59}$ Therefore he asserts in the first chapter of his encyclical Ut Unum Sint that ecumenical martyrs 'are the most powerful proof that every factor of division can be transcended and overcome in the total gift of self for the sake of the Gospel'. ${ }^{60}$ Following in these footsteps, Pope Francis repeatedly points out that at least for their persecutors Christians are not divided and not killed because they are Orthodox,

${ }^{55} \mathrm{Cf}$. Francis, 'Address of His Holiness Pope Francis at the Audience with Representatives of the Churches and Ecclesial Communities and of the Different Religions (20 March, 2013)'. For a first assessment of these early ecumenical steps cf. Mayer, 'Pope Francis: a Pastor According to the Heart of Christ', 147-60; especially 157 and Scerri, 'The Ecumenical Commitment of Pope Francis', 25-42.

${ }^{56}$ lbid.

${ }^{57}$ With this Pope Francis continues the tradition of Tertullian, Apologeticum 50, 13, CCL 1, 171:'sanguis martyrum semen christianorum' - the blood of the martyrs is the seed of new Christians.

${ }^{58}$ Second Vatican Council, 'Decree on Ecumenism Unitatis Redintegratio (1965)', no. 4, 413.

${ }^{59}$ John Paul II, 'Apostolic Letter Tertio Millennio Adveniente (10 November, 1994)', no. 37. The Pope explains: 'At the end of the second millennium, the Church has once again become a Church of martyrs. The persecutions of believers - priests, Religious and laity - has caused a great sowing of martyrdom in different parts of the world. The witness to Christ borne even to the shedding of blood has become a common inheritance of Catholics, Orthodox, Anglicans and Protestants, as Pope Paul VI pointed out in his Homily for the Canonisation of the Ugandan Martyrs..'

${ }^{60} \mathrm{John}$ Paul II, Ut Unum Sint, no. 1: 'The courageous witness of so many martyrs of our century, including members of Churches and Ecclesial Communities not in full communion with the Catholic Church, gives new vigour to the Council's call and reminds us of our duty to listen to and put into practice its exhortation. These brothers and sisters of ours, united in the selfless offering of their lives for the Kingdom of God, are the most powerful proof that every factor of division can be transcended and overcome in the total gift of self for the sake of the Gospel.' Cf. also John Paul II, 'Homily at the Ecumenical Commemoration of the Witnesses to the Faith in the Twentieth Century' in the Colosseum (7 May 2000), no. 1 and idem, 'Apostolic Letter Novo Millennio Ineunte (6 January, 2001)', no. 7. 
Lutherans, Catholics, Pentecostals or whatever, but because of their jointly being Christian. Therefore, cooperation against the persecution of Christians worldwide was the subject of the first joint declaration ever signed by a Pope and a Patriarch of Moscow. In a letter to the members of the Anglican-Roman Catholic International Commission (ARCIC III), Pope Francis described the term 'ecumenism of blood' in April 2015:

There is a strong bond that already unites us which goes beyond all divisions: it is the testimony of Christians from different Churches and traditions, victims of persecution and violence simply because of the faith they profess. And not only now, that there are many of them: I think also of the martyrs of Uganda, half Catholics and half Anglicans. The blood of these martyrs will nourish a new era of ecumenical commitment, a fervent desire to fulfil the last will and testament of the Lord: that all may be one (cf. John 17:21). The witness by these our brothers and sisters demands that we live in harmony with the gospel and that we strive with determination to fulfil the Lord's will for his Church. ${ }^{61}$

It remains to be seen what fruits an ecumenical exploration of this paradigm can bring, for according to Pope Francis, unity is created in the journeying itself, but only if we are on the move together.

\section{Disclosure statement}

No potential conflict of interest was reported by the author.

\section{Notes on contributor}

Annemarie C. Mayer is professor of Systematic Theology and the Study of Religions in the Faculty of Theology and Religious Studies of the Katholieke Universiteit (Catholic University) Leuven, Belgium, and one of the academic editors of this journal. She serves on the Reformed-Catholic International Dialogue and on the Joint Working Group between the WCC and the Roman Catholic Church. Until 2013 she held the post of Catholic Consultant to the World Council of Churches in Geneva and taught Fundamental Theology at the University of Fribourg, Switzerland. Until 2010 she taught at the Institute for Ecumenical Research in the Catholic Faculty of Tübingen University, Germany.

\section{References}

Anhelm, Fritz Erich. 'Fundamentalismus und Beliebigkeit - pathologische Begleiterscheinungen der Moderne?' Ökumenische Rundschau 55 (2006): 77-79.

Bergoglio, Jorge Mario, and Abraham Skorka. On Heaven and Earth. Pope Francis on Faith, Family, and the Church in the Twenty-First Century. Trans. Alejandro Bermudez and Howard Goodman. New York: Image/Random House, 2010. (Spanish orig. Buenos Aires: Seix Barral 1995).

Berlinski, Claire. There Is No Alternative: Why Margaret Thatcher Matters. New York: Basic Books, 2010.

Best, Thomas F., with Lorelei F. Fuchs, SA, John Gibaut, Jeffrey Gros, FSC, and Despina Prassas. Growth in Agreement vol. IV, book 1 and book 2, International Dialogue Texts and Agreed Statements, 2004-2014. Faith and Order Paper 219. Geneva: World Council of Churches Publications, 2017.

Bevans, Stephen B. 'The Apostolic Exhortation Evangelii Gaudium on the Proclamation of the Gospel in Today’s World: Implications And Prospects'. International Review of Mission 103, no. 2 (2014): 297-308.

\footnotetext{
${ }^{61}$ Francis, 'Address of His Holiness Pope Francis to Members of the Anglican-Roman Catholic International Commission (ARCIC) (30 April, 2015)'.
} 
Congregation for the Doctrine of the Faith. 'Declaration Dominus Iesus on the Unicity and Salvific Universality of Jesus Christ and the Church (6 August, 2000)'. Acta Apostolicae Sedis (AAS) 92 (2000): 742-765 http://www.vatican.va/roman_curia/congregations/cfaith/documents/rc_con_ cfaith_doc_20000806_dominus-iesus_en.html.

Craughwell, Thomas J. Pope Francis. The Pope from the End of the Earth, foreword Cardinal Sean O'Malley. Bangalore: Asian Trading Corporation, 2013.

Dieter, Theodor. 'The Ecumenical Commemoration of the 500th Anniversary of the Reformation in Western Europe. International Journal for the Study of the Christian Church 17, no. 1 (2017): 11-25.

Ernesti, Jörg. 'Papst Franziskus - ein Solitär der jüngeren Papstgeschichte?'. In idem, Papst Franziskus: Herausforderung für Theologie und Kirche, ed. Martin Lintner and Markus Moling, 47-58. Innsbruck: Tyrolia, 2016.

Faith and Order Commission. The Third World Conference on Faith and Order, Lund, Sweden, 1952, ed. O. Tompkins. London: SCM Press, 1953.

Francis, Pope. 'Address of His Holiness Pope Francis at the Audience with Representatives of the Churches and Ecclesial Communities and of the Different Religions' (20 March, 2013). https:// w2.vatican.va/content/francesco/en/speeches/2013/march/documents/papa-francesco_20130320_ delegati-fraterni.html (accessed August 23, 2017).

Francis, Pope. 'Apostolic Exhortation Evangelii Gaudium on the Proclamation of the Gospel in Today's World' (24 November, 2013). AAS 105 (2013): 1019-1137 (English version). http://w2.vatican.va/ content/francesco/en/apost_exhortations/documents/papa-francesco_esortazione-ap_20131124_ evangelii-gaudium.html (accessed August 23, 2017).

Francis, Pope. 'Encyclical Letter on Faith Lumen Fidei' (29 June, 2013). AAS 105 (2013): 555-596. http://w2.vatican.va/content/francesco/en/encyclicals/documents/papa-francesco_20130629_ enciclica-lumen-fidei.html (accessed August 23, 2017).

Francis, Pope. 'Address of his Holiness Pope Francis at the Ceremony Commemorating the 50th Anniversary of the Institution of the Synod of Bishops' (17 October 2015). http://w2.vatican. $\mathrm{va} /$ content/francesco/en/speeches/2015/october/documents/papa-francesco_20151017_50anniversario-sinodo.html (accessed August 23, 2017).

Francis, Pope. 'Address of his Holiness Pope Francis in Conclusion of the Synod of Bishops' (24 October 2015). http://w2.vatican.va/content/francesco/en/speeches/2015/october/documents/ papa-francesco_20151024_sinodo-conclusione-lavori.html (accessed August 23, 2017).

Francis, Pope. 'Address of His Holiness Pope Francis to Members of the Anglican-Roman Catholic International Commission (ARCIC)' (30 April 2015). http://w2.vatican.va/content/francesco/ en/speeches/2015/april/documents/papa-francesco_20150430_commissione-internazionaleanglicana-cattolica.html (accessed August 23, 2017).

Francis, Pope. 'Common Declaration with Patriarch Kirill' (February 2016) http://w2.vatican.

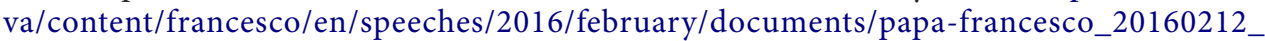
dichiarazione-comune-kirill.html.

Francis, Pope. 'Sermon at the Common Ecumenical Prayer at the Lutheran Cathedral of Lund' (31 October 2016). https://w2.vatican.va/content/francesco/en/homilies/2016/documents/papafrancesco_20161031_omelia-svezia-lund.html.

Huber, Wolfgang. 'Was bedeutet Ökumene der Profile?' In 'Kein Anlass zur Verwerfung'. Studien zur Hermeneutik des ökumenischen Gesprächs (FS Otto Hermann Pesch), ed. Johannes Brosseder, Markus Wriedt, 399-410. Frankfurt am Main: Lembeck, 2007.

Ivereigh, Austen. The Great Reformer: Francis - the Making of a Radical Pope. London: Allen \& Unwin, 2014.

John XXIII, Pope. 'Speech at the solemn inauguration of the Second Vatican Council Gaudet Mater Ecclesia' (11 October 1962). AAS 54 (1962): 786-796.

John Paul II, Pope. 'Apostolic Letter Tertio Millennio Adveniente (10 November, 1994)'. AAS 87 (1995): 5-41. https://w2.vatican.va/content/john-paul-ii/en/apost_letters/1994/documents/hf_jpii_apl_19941110_tertio-millennio-adveniente.html.

John Paul II, Pope. 'Encyclical Letter Ut unum sint' (25 May 1995). AAS 87 (1995): 977-978. http:// w2.vatican.va/content/john-paul-ii/en/encyclicals/documents/hf_jp-ii_enc_25051995_ut-unumsint.html. 
John Paul II, Pope. 'Homily at the Ecumenical Commemoration of the Witnesses to the Faith in the Twentieth Century', in the Colosseum (7 May 2000). https://w2.vatican.va/content/john-paul-ii/ en/homilies/2000/documents/hf_jp-ii_hom_20000507_test-fede.html.

John Paul II, Pope. 'Post-Synodal Apostolic Exhortation Ecclesia in Asia (6 November 1999)'. AAS 92 (2000): 482-487. http://w2.vatican.va/content/john-paul-ii/en/apost_exhortations/documents/ hf_jp-ii_exh_06111999_ecclesia-in-asia.html.

John Paul II, Pope. 'Apostolic Letter Novo Millennio Ineunte' (6 January, 2001). AAS 93 (2001): 266-309 https://w2.vatican.va/content/john-paul-ii/en/apost_letters/2001/documents/hf_jpii_apl_20010106_novo-millennio-ineunte.html.

Koch, Kurt Cardinal. 'Why a Common Commemoration of the Reformation?' International Journal for the Study of the Christian Church 17, no. 1 (2017): 3-10.

Lehmann, Karl. 'Was bedeutet “Ökumene der Profile”?' In 'Kein Anlass zur Verwerfung'. Studien zur Hermeneutik des ökumenischen Gesprächs (FS Otto Hermann Pesch), ed. Johannes Brosseder, Markus Wriedt, 411-421. Frankfurt am Main: Lembeck, 2007.

Luther, Martin. De servo arbitrio (1525), Weimarer Ausgabe (WA) vol. 18, ed. Joachim K.F. Knaake et al., Weimar: H. Böhlaus, 1883-1929, 551-787. https://archive.org/stream/ werkekritischege18luthuoft\#page/786/mode/2up.

Luther, Martin. Vorrede zum Jakobusbrief (1522/1546), Weimarer Ausgabe, Die deutsche Bibel vol. 7, ed. Joachim K.F. Knaake et al., 385-387. Weimar: H. Böhlaus, 1906.

Lutheran World Federation and Pontifical Council for Promoting Christian Unity. From Conflict to Communion: Lutheran-Catholic Common Commemoration of the Reformation in 2017. Leipzig: Evangelische Verlagsanstalt and Paderborn: Bonifatius Verlag, 2013.

Mayer, Annemarie C. 'Pope Francis: a Pastor According to the Heart of Christ'. International Journal for the Study of the Christian Church 13, no. 2 (2013): 147-160.

Mayer, Annemarie C. 'Was liegt heute prospektiv für Theologie und Kirche in ökumenischer Hinsicht an?' In Das Zweite Vatikanische Konzil: Programmatik - Rezeption - Vision: Tagung der Arbeitsgemeinschaft der Dogmatiker und Fundamentaltheologen im deutschsprachigen Raum, Freising 17. bis 20. September 2012, ed. Christoph Böttigheimer (Quaestiones disputatae 261), 238-254. Freiburg i. Br.: Herder, 2014.

Müller-Fahrenholz, Geiko. 'Zwischen Fundamentalismus und Beliebigkeit'. Ökumenische Rundschau 55 (2006): 68-76.

Oberdorfer, Bernd. 'Konsensökumene? Differenzökumene? Ökumene der Profile?: Ulrich Körtners Beitrag zur neueren Diskussion um Leitvorstellungen des ökumenischen Gesprächs'. Kerygma und Dogma 55, no. 1 (2009): 39-51.

O'Collins, Gerald. 'Pope Francis and the Second Vatican Council (1962-65)'. The Australasian Catholic Record 93, no. 2 (Apr 2016): 209-216.

O'Connell, Gerard. 'Francis Calls For Decentralization And “Conversion” Of The Papacy'. America 213, no. 13 (2015): 9-10.

Scannone, Juan S. J. Carlos. 'Pope Francis and the Theology of the People'. Theological Studies 77, no. 1 (2016): 118-135.

Scerri, Hector. 'The Ecumenical Commitment of Pope Francis'. Roczniki Teologii Ekumenicznej 60, no. 5 (2013): 25-42.

Schmidt S. J., Markus. 'Der Papst hat dafür in Turin den Ton angegeben, aber andere werden die Musik schreiben'. Ökumenisches Handeln bei Papst Franziskus'. In Papst Franziskus: ein erstes Resümee, eds. Monika Datterl et al., 99-118. Innsbruck: Innsbruck University Press, 2016.

Second Vatican Council. 'Decree on Ecumenism Unitatis Redintegratio' (1965). In Vatican Council II. The Conciliar and Post Conciliar Documents, ed. Flannery O. P. Austin, vol. 1, 408-424. Reprint of 1975, Mumbai: St Pauls, 2010.

Second Vatican Council. 'Dogmatic Constitution on the Church Lumen Gentium' (1965). In Vatican Council II. The Conciliar and Post Conciliar Documents, ed. Flannery O. P. Austin, vol. 1, 320-390. Reprint of 1975, Mumbai: St Pauls, 2010.

Spadaro, Antonio S.J., and Marcelo Figueroa. 'Evangelical Fundamentalism and Catholic Integralism in the USA: A Surprising Ecumenism'. Civiltà Cattolica. https://laciviltacattolica.com/uncategorized/ 
evangelical-fundamentalism-and-catholic-integralism-in-the-usa-a-surprising-ecumenism/ (accessed 15 July, 2017).

Tagle, Luis Antonio. 'A November Storm: The Black Week'. In History of Vatican II, vol. 4: Church as Communion: Third Period and Intersession, September 1964-September 1965, ed. Giuseppe Alberigo and Joseph A. Komonchak, 387-452. Maryknoll: Orbis and Leuven: Peeters 2003.

Tertullian. Apologeticum, ed. Corpus Christianorum, Series Latina, 1, 77-172, edited by Dom Eligius Dekkers. Brepols: Turnhout, 1953.

Vatican Press Office, 'Personal visit of His Holiness Pope Francis to Caserta to meet with the evangelical pastor Giovanni Traettino', 28 July 2014 (http://press.vatican.va/content/salastampa/de/bollettino/ pubblico/2014/07/28/0542/01200.html; accessed 23/08/2017).

Wąsek, Damian. 'Neuausrichtung des Papsttums - Legitimität, Konfliktpunkte und Wandel.' In Barmherzigkeit und zärtliche Liebe. Das theologische Programm von Papst Franziskus, ed. Kurt Appel and Jakob H. Deibl, 366-378. Freiburg i. Br., Basel and Wien: Herder, 2016.

Welby, Justin. 'Presidential Address to the General Synod of the Church of England' (15 February 2016). http://www.archbishopofcanterbury.org/articles.php/5669/archbishop-reflects-on-primatesmeeting-in-synod-address-video (accessed August 23, 2017).

Wooden, Cindy. 'Communion of Saints can Intercede for Christian Unity, Cardinal Says'. Catholic News Service. http://www.catholicnews.com/services/englishnews/2017/communion-of-saintscan-intercede-for-christian-unity-cardinal-says.cfm (accessed 28 July, 2017). 